\title{
PENGARUH MEDIA DAN HORMON TUMBUH AKAR TERHADAP KEBERHASILAN CANGKOK ULIN
}

\author{
The Effect of Media and Root Growth Hormone on the Successfulness of Ulin Air Layering
}

\author{
Kurniawati P. Putri, Dharmawati F.D, dan/and Made Suartana \\ Balai Penelitian Teknologi Perbenihan Bogor \\ Jl. Pakuan Ciheuleut PO. BOX 105, Bogor - 16001, Telp./Fax. (0251) 327768
}

Naskah masuk: 3 Oktober 2006 ; Naskah diterima: 12 Juli 2007

\begin{abstract}
Ulin (Eusideroxylon zwagery) is one of commercial demanded wood types that becomes rare because there are no real conservation and reservation for this plant. The goal of this research was to determine the influence of the media and Rootone-F (root growth hormone) for the success of ulin (E. zwagery) transplant efficacy. The design of the research was complete random $3 \times 2$ factorial designs (CRD) with 4 repetitions on each treatment. Transplant media factors based on the ground - fertilize mixture with comparison 1:1, manure fertilizer, and coconut coir powder. Growth hormone factors consist of control (without growth hormone) and the Rootone-F. Parameters that observed are root percentage, diameter of root and length of the root. The result of the research neither showed that nor transplant media and Rootone-F did not influence the root percentage, diameter of root and length of the root. Interaction between media mixture fertilizer-soil with comparation of $1: 1$ and Rootone-F resulted on highest percentage of root that was $88,89 \%$.
\end{abstract}

Key words : Eusideroxylon zwagery, air layering, medium, growth hormone, Rootone-F

\begin{abstract}
ABSTRAK
Ulin (Eusideroxylon zwagery) merupakan salah satu jenis kayu komersial yang banyak diminati dan semakin langka karena tidak adanya upaya konservasi dan budidaya terhadap tanaman ulin. Penelitian ini bertujuan untuk mengetahui pengaruh media dan hormon tumbuh Rootone-F terhadap keberhasilan cangkok ulin ( $E$. zwagery). Rancangan penelitian yang digunakan adalah rancangan faktorial 3 X 2 dalam disain acak lengkap (CRD) dengan 4 ulangan untuk setiap kombinasi perlakuan. Faktor media cangkok terdiri dari campuran tanah pupuk kandang dengan perbandingan $1: 1$, pupuk kandang, dan serbuk sabut kelapa. Faktor hormon tumbuh terdiri dari kontrol (tanpa hormon tumbuh) dan hormon tumbuh rootone-F. Parameter yang diamati adalah persentase berakar, diameter akar dan panjang akar. Hasil penelitian menunjukkan bahwa media cangkok maupun hormon tumbuh Rootone-F tidak mempengaruhi persentase berakar, diameter akar dan panjang akar. Interaksi antara media campuran pupuk kandang - tanah perbandingan $1: 1$ dengan hormon tumbuh Rootone-F menghasilkan persentase berakar tertinggi yaitu sebesar $88,89 \%$.
\end{abstract}

Kata Kunci : $\quad$ Eusideroxylon zwagery, cangkok, media, hormon tumbuh, Rootone-F

\section{PENDAHULUAN}

Ulin (Eusideroxylon zwagery) merupakan salah satu jenis kayu komersial yang banyak diminati terutama karena sifat kekuatan dan keawetannya. Hingga saat ini pemenuhan kebutuhan terhadap kayu ulin masih mengandalkan pada potensi sumber daya hutan alam. Selain kegiatan over eksploitasi tersebut, kelangkaan tegakan ulin di alam juga tidak terlepas dari sifat pertumbuhannya yang sangat lambat. Untuk mendapatkan tanaman ulin dewasa dengan ukuran diameter batang yang cukup besar memerlukan waktu sekitar \pm 80 tahun (Idhani, 1999). Melihat kondisi tersebut, maka 
perlu adanya upaya konservasi baik in-situ maupun ex-situ. Keberhasilan pembangunan konservasi terutama secara ex-situ diantaranya harus didukung dengan teknik perbanyakan tanaman yang tepat.

Perbanyakan ulin secara generatif mempunyai beberapa permasalahan antara lain sifat benih ulin yang sulit berkecambah secara alami. Benih ulin mempunyai kulit yang tebal dan keras, sehingga untuk proses perkecambahan membutuhkan waktu lama yaitu sekitar 6 - 12 bulan dengan viabilitas yang cukup rendah (Idhani, 1999). Berdasarkan hal tersebut, teknik perbanyakan vegetatif dapat menjadi alternatif untuk memperbanyak tanaman ulin. Perbanyakan vegetatif merupakan teknik perbanyakan yang menggunakan bagian vegetatif tanaman untuk ditumbuhkan menjadi tanaman sempurna. Keuntungan dari perbanyakan tanaman secara vegetatif adalah dapat dilaksanakan pada saat diperlukan, dan mampu menyediakan bibit dalam jumlah yang banyak. Selain itu bibit yang dihasilkan akan memiliki susunan genetik yang sama dengan induknya. Perbanyakan vegetatif ulin telah diupayakan dengan teknik pembiakan vegetatif stek, tetapi persentase berakar yang dihasilkannya masih rendah. Subiakto (2005) melaporkan bahwa perbanyakan vegetatif ulin secara stek dengan menggunakan media campuran serbuk sabut kelapa - sekam padi perbandingan $2: 1$ serta diberikan hormon tumbuh Rootone-F menghasilkan persentase berakar sebesar $69 \%$. Berdasarkan hal tersebut, maka perlu adanya teknik perbanyakan vegetatif lain yang diharapkan dapat meningkatkan keberhasilan perbanyakan vegetatif ulin.

Atas dasar pertimbangan tersebut di atas, maka dilakukan penelitian perbanyakan vegetatif cangkok untuk jenis ulin (E. zwagery) dengan perlakuan media cangkok dan penambahan hormon tumbuh Rootone-F. Tujuan penelitian ini adalah untuk mengetahui pengaruh media dan penambahan hormon tumbuh Rootone-F terhadap keberhasilan cangkok ulin (E. zwagery).

\section{BAHAN DAN METODE}

\section{A. Bahan dan Lokasi Penelitian}

Penelitian ini dilaksanakan di kebun percobaan Nagrak, Balai Litbang Teknologi Perbenihan pada bulan Maret hingga bulan Oktober 2004.

\section{B. Bahan dan Alat Penelitian}

Bahan yang digunakan adalah bagian vegetatif dari pohon ulin (E. zwagery) umur 6,5 tahun yang benihnya berasal dari Kalimantan Barat. Bahan lain yang digunakan antara lain tanah top soil, kotoran kambing, serbuk sabut kelapa, dan Rootone F. Sedangkan alat yang digunakan berupa plastik transparan, tali pengikat, kaliper, mistar, ember, pisau cangkok, kertas label dan alat tulis.

\section{Metode Penelitian}

1. Rancangan penelitian

Rancangan yang digunakan dalam penelitian ini adalah rancangan faktorial 3 X 2 dalam disain acak lengkap (CRD) dengan 4 ulangan untuk setiap kombinasi perlakuan.

Faktor media cangkok (A) :

A 1 = campuran tanah - pupuk kandang dengan perbandingan $1: 1$

A 2 = pupuk kandang

A 3 = serbuk sabut kelapa 
Faktor hormon tumbuh (B) :

B $1=$ kontrol (tanpa hormon tumbuh)

B 2 = hormon tumbuh rootone-F

Parameter yang diamati adalah persentase berakar, diameter akar dan panjang akar.

Selanjutnya data hasil pengamatan dianalisa keragamannya dan apabila hasil uji tersebut berbeda nyata, maka dilanjutkan dengan uji lanjut Duncan.

2. Prosedur penelitian

Sebelum melakukan pencangkokan, dilakukan pemilihan cabang pohon yang akan dicangkok. Cabang pohon yang dipilih adalah cabang autotrop yang telah berkayu dengan ukuran diameter batang $\pm 3 \mathrm{~cm}$. Selanjutnya pencangkokan dapat dimulai dengan menyayat kulit batang dan mengerik kambiumnya sepanjang $5-10 \mathrm{~cm}$. Kemudian sayatan tersebut dikeringkan selama 2 hari sampai permukaan sayatan tidak bergetah lagi. Setelah kering, sayatan diolesi hormon tumbuh yang berbentuk pasta dan selanjutnya dibungkus dengan media sesuai dengan rancangan penelitian. Media ditutup dengan plastik transparan, dan diikat dengan tali pada bagian atas, bawah dan tengah dari cangkok. Pengamatan mulai dilakukan setelah timbulnya akar sampai cangkok siap untuk disapih.

\section{HASIL DAN PEMBAHASAN}

Keberhasilan pembiakan vegetatif dapat dilihat dari terbentuknya sistem perakaran. Untuk mendukung keberhasilan tersebut sangat diperlukan kondisi fisiologis tanaman yang tepat dan kondisi lingkungan yang optimal untuk proses pembentukan akar (Hartman et al., 1990). Pembentukan akar pada cangkok terjadi karena adanya penyayatan pada kulit batang yang menyebabkan pergerakan karbohidrat ke arah bawah terbendung di bagian atas sayatan. Pada bagian tersebut akan menumpuk karbohidrat dan auxin, dan dengan adanya media perakaran yang baik karbohidrat dan auxin tersebut akan menstimulir timbulnya akar (Rokhiman dan Harjadi, 1973). Media perakaran cangkok yang baik adalah media yang memiliki sifat drainase, aerasi dan kandungan unsur hara yang dapat mendukung pertumbuhan dan perkembangan akar cangkok. 
Tabel (Table) 1. Hasil analisa keragaman perlakuan media cangkok dan hormone Rootone-F pada cangkok ulin (E. zwagery) umur 8 bulan (the result of variability analysis of the treatment of transplant media and Rootone-F on 8 months age of ulin transplant)

\begin{tabular}{|c|c|c|c|c|}
\hline $\begin{array}{l}\text { Sumber keragaman } \\
\text { (source of variation) }\end{array}$ & $\begin{array}{l}\text { Derajat } \\
\text { bebas } \\
\text { (degree of } \\
\text { freedom) }\end{array}$ & $\begin{array}{c}\text { Jumlah kuadrat } \\
\text { (number of square) }\end{array}$ & $\begin{array}{l}\text { Kuadrat tengah } \\
\text { (mean square) }\end{array}$ & F-hitung \\
\hline \multicolumn{5}{|c|}{ Persen berakar /rooting percentage } \\
\hline A & 2 & 864,5432 & 432,2716 & 0,78 \\
\hline B & 1 & 987,6049 & 987,6049 & 1,78 \\
\hline $\mathrm{A} * \mathrm{~B}$ & 2 & 4568,1728 & $2.284,0864$ & $4,11 *$ \\
\hline Galat/Error & 12 & $6.667,1112$ & 555,5926 & \\
\hline \multicolumn{5}{|l|}{ Diameter akar/root diameter } \\
\hline A & 2 & 1,4237 & 0,7119 & 0,38 \\
\hline B & 1 & 0,8741 & 0,8741 & 0,46 \\
\hline $\mathrm{A} * \mathrm{~B}$ & 2 & 4,8805 & 2,4402 & 1,30 \\
\hline Galat/Error & 12 & 22,5689 & 1,8807 & \\
\hline \multicolumn{5}{|l|}{ Panjang akar root length } \\
\hline A & 2 & 0,3388 & 0,1694 & 0,05 \\
\hline B & 1 & 0,7361 & 0,7361 & 0,22 \\
\hline$A * B$ & 2 & 10,7799 & 5,3900 & 1,64 \\
\hline Galat/Error & 12 & 39,5033 & 3,2919 & \\
\hline
\end{tabular}

Keterangan (remark): * = berbeda nyata pada taraf uji $5 \%(*$ = significantly different at $p$ (5 level)

Berdasarkan hasil analisa keragaman (Tabel 1) diketahui bahwa persentase berakar, diameter akar serta panjang akar yang dihasilkan oleh cangkok ulin (E. zwagery) tidak dipengaruhi oleh media yang digunakan. Hal tersebut menunjukkan bahwa penggunaan ketiga macam media cangkok menghasilkan persentase berakar, diameter akar dan panjang akar yang sama. Hasil analisa keragaman juga menunjukkan bahwa persentase berakar, diameter akar serta panjang akar yang dihasilkan oleh cangkok ulin tidak dipengaruhi oleh hormon tumbuh Rootone-F. Dengan demikian cangkok ulin (E. zwagery) yang menggunakan hormon tumbuh Rootone-F maupun yang tidak menggunakan hormon tumbuh Rootone-F akan menghasilkan persentase berakar, diameter akar dan panjang akar yang relatif sama. Tidak adanya perbedaan nyata tersebut diduga karena lambatnya pertumbuhan dan perkembangan akar cangkok ulin (E. zwagery). Dalam penelitian ini proses terbentuknya kalus pada kambium yang luka membutuhkan waktu 3 bulan, kemudian untuk mencapai kondisi perakaran yang siap sapih diperlukan waktu 5 bulan. Keberhasilan cangkok diantaranya ditentukan oleh ketepatan waktu pelaksanaan, karena akan berhubungan dengan kondisi fisiologis tanaman. Waktu yang tepat untuk melakukan pencangkokan adalah pada saat pertumbuhan vegetatif dimulai atau pada saat aliran makanan tertuju ke arah bawah. Sehingga sebaiknya pencangkokan dilakukan pada awal musim hujan yaitu pada saat dimulainya pertumbuhan vegetatif (Bramasto et al., 1998).

Dari analisa keragaman diketahui interaksi antara media dan hormon tumbuh Rootone-F hanya berpengaruh pada persentase akar cangkok ulin (E. zwagery). Pengujian lanjutan terhadap nilai rata-rata (Tabel 2) memperlihatkan bahwa kombinasi yang terbaik adalah media campuran pupuk kandang - tanah perbandingan $1: 1$ dan hormon tumbuh Rootone-F, karena menghasilkan persentase perakaran tertinggi (88,89 \%). Media tanam menyediakan unsur hara yang diperlukan akar, sedangkan hormon tumbuh memobilisasi unsur hara tersebut (Nanda and Anand, 1970). Hormon tumbuh 
Rootone-F berperan dalam proses pertumbuhan dan perkembangan akar cangkok ulin, sehingga keberadaannya akan lebih efektif bila ditunjang dengan media tanam yang optimal. Lebih lanjut Suhaendi (2000) menegaskan bahwa pemberian hormon tumbuh akan meningkatkan kualitas dan kuantitas perakaran yang terbentuk, apabila kondisi lingkungan yang menguntungkan serta pemilihan bahan tanamannya sangat diperhatikan. Penambahan pupuk kandang pada media tanah menyebabkan meningkatnya porositas dan aerasi tanah, dimana diketahui bahwa media tanah bersifat padat sehingga aerasinya kurang baik. Schmidt (2002) menyatakan bahwa struktur fisik media merupakan hal yang menentukan dalam proses perakaran. Media yang baik adalah media yang memenuhi persyaratan keseimbangan antara kelembaban dan aerasi. Penambahan pupuk kandang juga berperan dalam meningkatkan kesuburan, karena pupuk kandang mengandung unsur hara yang cukup tinggi. Tisdole and Nelson (1965) dalam Syamsuwida et al. (2001) menyatakan bahwa pupuk kandang yang berasal dari kotoran kambing mengandung unsur hara yang cukup tinggi yaitu 0,75\% untuk N, 0,5\% untuk $\mathrm{P}_{2} \mathrm{O}_{5}$ dan $0,45 \%$ untuk $\mathrm{K}_{2} \mathrm{O}$.

Tabel (Table) 2. Rata-rata persentase berakar, diameter akar dan panjang akar cangkok ulin (Average of rooting percentage, root diameter and root length of ulin transplant)

\begin{tabular}{|c|c|c|c|c|}
\hline \multirow{2}{*}{ No. } & \multirow{2}{*}{$\begin{array}{l}\text { Perlakuan } \\
\text { (treatment) }\end{array}$} & \multicolumn{3}{|c|}{$\begin{array}{l}\text { Parameter pertumbuhan cangkok ulin } \\
\text { (growth parameter of ulin's transplant) }\end{array}$} \\
\hline & & $\begin{array}{c}\text { Persentase berakar } \\
\text { (rooting percentage) } \\
\text { (\%) }\end{array}$ & $\begin{array}{c}\text { Diameter akar } \\
\text { (root diameter) } \\
(\mathrm{mm})\end{array}$ & $\begin{array}{c}\text { Panjang akar } \\
\text { (root length) } \\
\text { (cm) }\end{array}$ \\
\hline 1. & A1B1 & 33,33 a & 1,39 a & 2,06 a \\
\hline 2. & A1B2 & 88,89 & $2,96 \quad \mathrm{a}$ & $4,11 \quad \mathrm{a}$ \\
\hline 3. & A2B1 & $66,67 \quad b$ & $2,33 \quad \mathrm{a}$ & $3,00 \quad \mathrm{a}$ \\
\hline 4. & $\mathrm{~A} 2 \mathrm{~B} 2$ & $77,78 \quad$ b $\quad c$ & 3,03 a & 3,83 a \\
\hline 5. & A3B1 & $66,67 \quad b$ & $2,50 \quad \mathrm{a}$ & 4,03 a \\
\hline 6. & A3B2 & 44,44 a & 1,56 a & 2,36 a \\
\hline
\end{tabular}

Keterangan (remark): $\quad$ Angka-angka dalam kolom yang diikuti dengan huruf yang sama, tidak berbeda nyata pada taraf $\mathrm{P}<0,05$ (numbers in columns followed by different letters are insignificantly different on $P<0,05$ level)

Penggunaan serbuk sabut kelapa sebagai media cangkok belum menunjukkan hasil yang lebih baik dibandingkan media campuran tanah-pupuk kandang, walaupun serbuk sabut kelapa memiliki draenasi dan aerasi yang baik untuk pertumbuhan akar. Bila dilihat dari kemampuannya mengikat/menahan air, serbuk sabut kelapa memiliki kapasitas menahan air yang cukup tinggi yaitu mencapai 14,71 kali bobot keringnya (Sutater et al.,1998). Kapasitas memegang air tersebut sangat penting untuk menjaga kelembaban guna menghindari resiko kekeringan media (Singarum, 1994 dalam Syamsuwida et al., 2001). Selain itu media serbuk sabut kelapa juga mempunyai berat jenis yang cukup rendah yaitu 0,045 (Hendromono, 1998). Media dengan nilai berat jenis rendah akan memiliki ruang pori total (porositas) yang besar. Tingkat porositas media berkaitan dengan tingkat kesarangan media, sehingga semakin kecil berat jenisnya maka semakin tinggi tingkat kesarangannya. Kelebihan yang dimiliki oleh serbuk sabut kelapa tersebut ternyata tidak cukup untuk mendukung pertumbuhan dan perkembangan perakaran cangkok ulin (E. zwagery) yang cukup lama (8 bulan), 
karena tidak adanya unsur hara maupun jasad renik dalam media serbuk sabut kelapa. Unsur hara dan jasad renik sangat diperlukan untuk pertumbuhan dan perkembangan akar.

\section{KESIMPULAN}

Tidak ada perbedaan persentase berakar, diameter akar dan panjang akar cangkok ulin (E. zwagery) yang disebabkan perbedaan media cangkok maupun perbedaan hormon tumbuh RootoneF. Interaksi antara media campuran pupuk kandang - tanah perbandingan $1: 1$ dengan hormon tumbuh Rootone-F merupakan kombinasi perlakuan yang terbaik karena menghasilkan persentase berakar tertinggi $(88,89 \%)$.

\section{DAFTAR PUSTAKA}

Bramasto, Y., D. Syamsuwida, dan D. Iriantono. 1998. Pembuatan Cangkok dalam rangka Penyiapan Kebun Benik Klon Acacia mangium Willd. Buletin Teknologi Perbenihan 5 (2) : 129 -138. Balai Teknologi Perbenihan. Bogor.

Hartman, H. T., D.E. Kester and Davies. 1990. Plant Propagation Principles and Practices. Fifth edition. Prentice Hall Inc. Englewood Cliffs. New Jersey.

Hendromono. 1998. Pengaruh Media Organik dan Tanah Mineral terhadap Mutu Bibit Pterygota alata ROXB. Buletin Penelitian Hutan No. 617. Pusat Litbang Kehutanan. Bogor.

Idhani, D. M. 1999. Pelestarian Jenis Ulin (Eusyderoxylon zwageri) serta Upaya Pengembangannya. Prosiding Pertemuan Tahunan Jaringan Kerja Litbang Terpadu Perusahaan HTI Patungan Lingkup PT Inhutani I. Jakarta.

Nanda, K.K., and J.K. Anand. 1970. Seasonal Change in Auxine Effect on Rooting of Populus nigra and Its Relationship with Mobilistation of Starch. Ann. Rev. Plant Physiol 23 : 99 - 107.

Rochiman, K. dan S.S. Harjadi. 1973. Pembiakan Vegetatif. Diktat Pengantar Agronomi. Departemen Agronomi. Fakultas Pertanian. Institut Pertanian Bogor. (Tidak diterbitkan).

Schmidt, L. 2002. Pedoman dan Penanganan Benih Tanaman Hutan Tropis dan Sub Tropis. Direktorat Jenderal Rehabilitasi Lahan dan Perhutanan Sosial, Departemen Kehutanan. Jakarta. hal 349 - 350.

Subiakto, A. 2002. Stek Pucuk Jenis Kayu Mewah (Ebony dan Ulin). Prosiding Diskusi Hasil-Hasil Litbang Rehabilitasi dan Konservasi Sumberdaya Hutan. Pusat Penelitian dan Pengembangan Hutan dan Konservasi Alam. Departemen Kehutanan. Bogor. Hal 131-136.

Suhaendi, H. 2000. Pengaruh Zat Pengatur Tumbuh IBA dan Media Tumbuh terhadap Pertumbuhan Stek Eucalyptus deglupta Blume. Makalah dalam Ekspose Hasil-Hasil Penelitian Dengan Tema Peran Penelitian dan Pengembangan Kehutanan Dalam Upaya Peningkatan Produktivitas Hutan Untuk menunjang Otonomi Daerah. Pusat Penelitian dan Pengembangan Hutan dan Konservasi Alam. Bogor.

Sutater, T. Suciantini dan R. Tejasarwana. 1998. Serbuk Sabut Kelapa sebagai Media Tanam Krisan dalam Modernisasi Usaha Pertanian Berbasis Kelapa. Prosiding Konferensi Nasional Kelapa IV. Badan Penelitian dan Pengembangan Tanaman Industri. hal 293 - 300.

Syamsuwida, D., N. Yuniarti dan K.P. Putri. 2001. Pengaruh Penggunaan Pupuk, Media Semai dan Inokulasi Rhizobium pada Semai Kihiang (Albizia procera) dan Johar (Cassia siamea). Buletin Teknologi Perbenihan 8 (1) : 133 -146. Balai Teknologi Perbenihan. Bogor. 